\title{
Review Article Healthcare Workers' Knowledge about Chagas Disease: A Systematic Review
}

\author{
Alice Monteiro Soares Cajaiba-Soares, ${ }^{1}$ Martha Silvia Martinez-Silveira, ${ }^{2}$ Diego Lopes Paim Miranda, ${ }^{1}$ \\ Rita de Cássia Pereira Fernandes, ${ }^{1}$ and Mitermayer Galvão Reis ${ }^{1,2,3 *}$ \\ ${ }^{1}$ Faculdade de Medicina da Bahia, Universidade Federal da Bahia (FAMEB-UFBA), Salvador, Brazil; ${ }^{2}$ Instituto Gonçalo Muniz, Fundação \\ Oswaldo Cruz (IGM-FIOCRUZ), Salvador, Brazil; ${ }^{3}$ Department of Epidemiology of Microbial Diseases, School of Public Health, Yale University, \\ New Haven, Connecticut
}

\begin{abstract}
Transmission of Chagas disease (CD) has decreased in recent decades, but the disease remains an important problem in endemic areas. There was an increase in the proportion of nonvector transmission, mainly in nonendemic countries. The aim of this study was to gather evidence concerning healthcare professional's knowledge about CD. Searches were performed through Medline/PubMed, Lilacs, Web of Science databases, and Scielo archives, from which 13/97 articles were selected for a qualitative analysis after full-text reading. Most of the studies were from the United States, the oldest published in 2007 and the most recent in 2020, and most of them used surveys as the evaluation method. Each article used different methods, according to the epidemiological status of vector transmission. Two studies targeted specialty-related questions, and two used focus groups as methods for data gathering. Despite differences between the studies, all of them presented knowledge deficits among healthcare workers, regarding at least one of the evaluated aspects. In comparison with population surveys, healthcare professionals demonstrated higher results related to clinical aspects and awareness of the disease's importance. Most of the articles showed a low perception of CD's knowledge by the participants and a low probability of considering CD in the diagnosis of their patients. A previous contact with the subject was pointed by some studies as capable of improving knowledge of the participants. This study emphasizes the importance of continuing education to address deficits of healthcare professionals' knowledge.
\end{abstract}

\section{INTRODUCTION}

Human Chagas disease (CD) was discovered by Carlos Chagas in 1909, at Lassance, Minas Gerais, Brazil. He initially described its clinical aspects, transmission vectors, and its etiological agent, Trypanosoma cruzi (T. cruzi). ${ }^{1,2}$ Insects of the Reduviidae family are mainly responsible for vector transmission, from which about 140 species have been described as potential transmitters. ${ }^{3}$

In the 1980s, the HIV epidemic highlighted the known possibility of transfusion transmission of infectious diseases, including CD. ${ }^{4}$ Furthermore, better control of vector circulation allowed for other forms of transmission to gather more visibility. As globalization spread around the world, vertical transmission became a key epidemiologic issue among non-endemic countries. ${ }^{5,6}$ Besides, in the past years, oral transmission has also been responsible for causing outbreaks of acute CD. ${ }^{7-9}$

Eight million people are estimated to be infected with $C D$ around the world, with approximately 236,000 disabilityadjusted life years (DALYs) mostly in Latin America, with more than 10,000 deaths/year. ${ }^{10,11}$ In South America, there are about 100 million people at risk of contracting CD, and 21 countries are endemic for the disease in the American continent. ${ }^{12}$ In Brazil, for example, most recent data, from 2014, showed that about 4.6 million people are infected with $T$. cruzi. ${ }^{13}$

A health surveillance system must target on the development of epidemiologic control integrated actions as a tool on infectious disease prevention. ${ }^{14} \mathrm{~A}$ multi-professional healthcare team (physician, nurses, and nurse assistants) is essential for the health surveillance system to work and for proper guidance and health care of a community. ${ }^{15}$ Community health workers are also identified to have an important role in primary care,

*Address correspondence to Mitermayer G. Reis, Instituto Gonçalo Moniz, Fundação Oswaldo Cruz, Ministério da Saúde, Waldemar Falcão Street, 121, Salvador, 40296-710, Bahia, Brazil. E-mail: mitermayer.reis@fiocruz.br connecting the community and the healthcare system. ${ }^{16}$ Falavigna-Guilherme et al. ${ }^{17}$ showed that initiatives targeting community and health workers' awareness can reduce the number of houses infested by the vector of CD. Thus, it is extremely important to verify the knowledge level of the health professionals about CD, as well as their capability on providing awareness for the community and development of interventions aiming the correction of local deficits. Training activities on the healthcare team are also necessary to improve their role as active agents on epidemiologic surveillance and prevention. This study aims to gather evidence about knowledge and perceptions about CD, as well as its transmission, diagnosis, prevention, and treatment by healthcare workers.

\section{MATERIALS AND METHODS}

A systematic review concerning healthcare workers' knowledge about CD and its transmission was conducted. Searches were performed through Medline/PubMed, Lilacs, and Web of Science databases, along with complementary gathering on SciELO electronic library until July 2020. In addition, references cited on selected articles were reviewed for further pertinent studies that matched the inclusion criteria. The report of this systematic review was based in the Preferred Reporting Items for Systematic Reviews and Meta-Analyses statement guidelines criteria. ${ }^{18}$

Inclusion and exclusion criteria. Observational studies that evaluated healthcare workers' knowledge about CD, as well as its diagnosis, treatment, form of transmission, and prevention, were selected. Research involving healthcare workers such as physicians of any specialty, nurses, nurse assistants, or community health workers individually or as a multidisciplinary group were considered for selection. Not original articles, reviews, systematic reviews, editorials, letters, and commentaries were excluded. Languages were English, Spanish, and Portuguese, and date of publication was not considered for exclusion. 
Search strategy and selection of studies. To conduct the research, search strategies were constructed with subject headings based on MeSH for Medline/PubMed and DeCS for Lilacs databases and then combined with keywords to amplify search sensibility. The search strategy for PubMed was ("CD"[MeSH Terms] OR “T. cruzi" [MeSH Terms] OR "triatominae"[MeSH Terms] OR "CD") AND ("Health personnel"[MeSH Terms] OR "Health personnel" OR "Allied health personnel" OR "Health Workers" OR "Nursing Assistants" OR nurses[Title/Abstract] OR Physicians[Title/Abstract] OR doctors [Title/Abstract] OR "Health professionals" OR "health care providers" OR "health agents" OR "health care") AND ("Knowledge"[MeSH Terms] OR "health knowledge, attitudes, practice"[MeSH Terms] OR ([knowledge OR awareness OR attitudes] AND Chagas[Title/Abstract]) OR "awareness"[MeSH Terms] OR "Attitude to health"[MeSH Terms] OR "Education, public health professional"'[MeSH Terms] OR "Attitude of health personnel"[MeSH Terms]). Then, the strategy was adapted for other databases according to their respective formats or languages.

Duplicates were excluded, and two reviewers performed a selection by title and abstract independently. Then, the selection was carried out after the full articles were pursued and read according to the inclusion criteria.

Quality evaluation and risk of bias. For evaluation of the methodological quality of included studies, a point system tool adapted from Critical Appraisal Skills Program qualitative checklist was used ${ }^{19}$. According to Madigan et al., ${ }^{20}$ quality was considered based on the number of affirmative answers, being low quality (0-2), moderate quality (3-5), and high quality (more than 6).

Results' evaluation and presentation. The results were divided according to vector transmission status of $\mathrm{CD}$ by the WHO Map Production, concerning distribution of cases. ${ }^{10}$ Thus, the studies were classified based on the country of data collection among the following: vector transmission in progress, accidental vector transmission, and absence of vector transmission.

Based on the CNS resolution no. 466/12, the ethics committee evaluation was waived.

\section{RESULTS}

A total of 97 articles were found, of which 80 were from PubMed/ Medline, six from Lilacs, 10 from Web of Science, one from SciELO, and five were excluded for being duplicates. Of the 80 remaining studies, 19 articles were found eligible for the study. After reading full text, six articles had to be excluded. One was excluded because it was a replica of another selected article published in a different year and journal, ${ }^{21}$ another was excluded for being a preliminary study that was later published as a full article, ${ }^{22}$ and four articles were excluded for not meeting the inclusion criteria (not being an observational study, ${ }^{23}$ do not evaluate CD knowledge ${ }^{17,24,25}$ ).

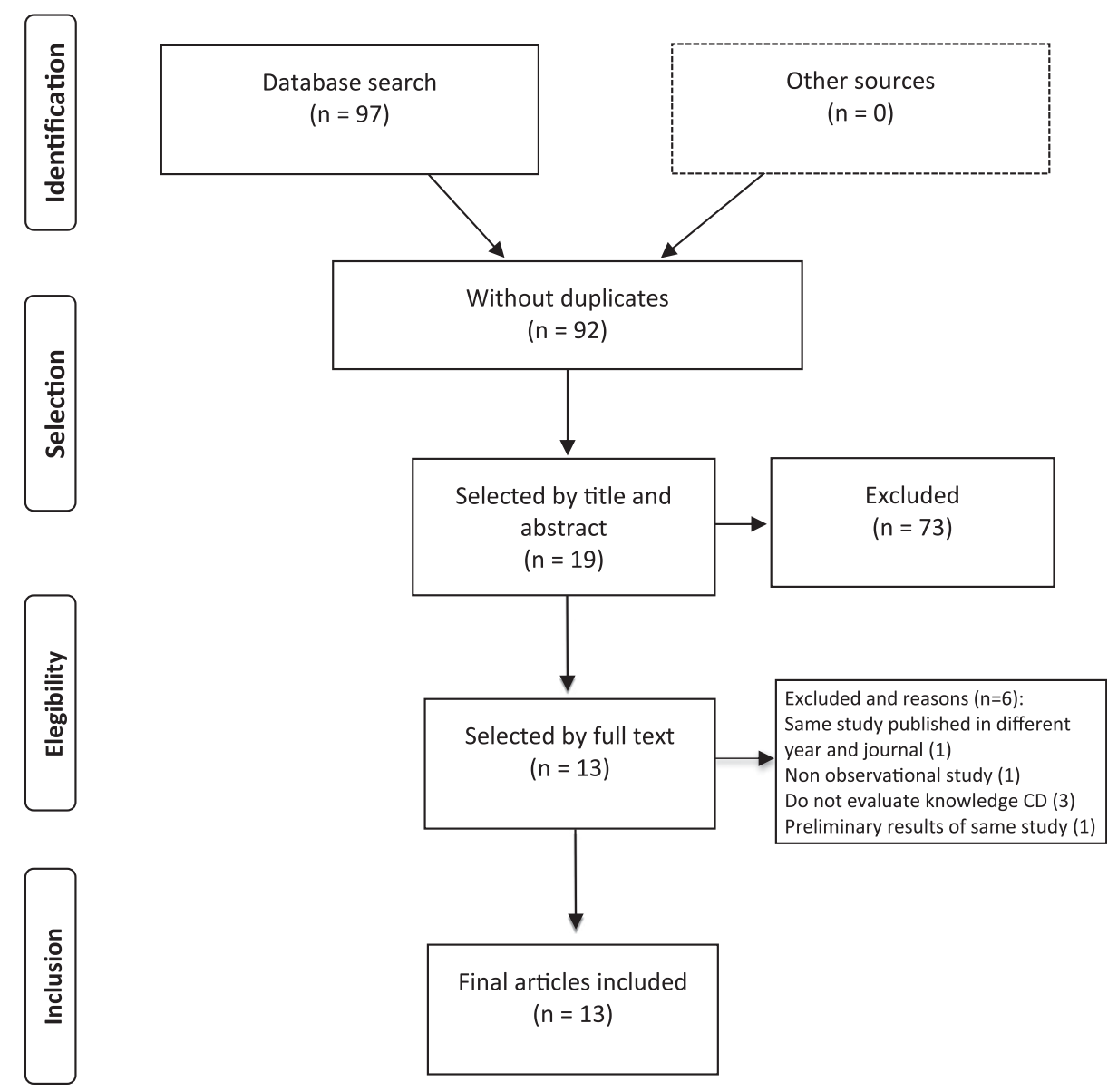

FIGURE 1. Flowchart of identification and selection of the articles used for systematic review of the literature about evaluation of health professionals' knowledge about Chagas disease. 
Finally, 13 articles were included in the descriptive analysis ${ }^{26-38}$ (Figure 1). Hand searches for additional references cited on selected articles did not result in further inclusion.

Among selected articles, the oldest was published in 2007 and the most recent in 2020. The most common language was English, ${ }^{26-31,34,36-38}$ followed by Spanish ${ }^{32,33}$ and Portuguese. ${ }^{35}$

Studies in countries with accidental vector transmission. There were five studies, all from the United States, $26,29,31,36,38$ with two of them being classified as high quality ${ }^{26,38}$ and the rest of them as moderate quality, ${ }^{29,31,36}$ as discriminated in Table 1. All studies were conducted through structured online surveys, except for Lambert et al.,, ${ }^{31}$ who applied a semi-structured survey. The selected studies' samples were only composed by physicians-two of them with only specialists, ${ }^{29,38}$ two with specialists and general physicians, ${ }^{26,36}$ and one with only general physicians. ${ }^{31}$ The study by Verani et al. ${ }^{38}$ was the only study to describe demographic characteristics of the sample.

Amstutz-Szalay, ${ }^{26}$ Stimpert and Montgomery, ${ }^{36}$ Verani et al., ${ }^{38}$ and Edwards et al. ${ }^{29}$ evaluated how often do healthcare workers considerate $\mathrm{CD}$ as diagnosis (Table 2). All studies suggested that most physicians had never considered $\mathrm{CD}$ as a diagnosis among patients on their clinical practice $\left(88.5 \%{ }^{26} ; 29-70 \%{ }^{36} ; 78 \%{ }^{38} ; 75.6 \%{ }^{29}\right)$. In these studies, selfperception of knowledge about CD was considered, resulting in frequencies of limited and very limited knowledge, around $27-68 \%,{ }^{36} 82.8 \%,{ }^{26}$ and $88.3 \%,{ }^{38} 68.1 \% .^{29}$ On the other hand, Edwards et al. ${ }^{29}$ evaluated healthcare workers' knowledge about congenital transmission of CD. Lambert et al. ${ }^{31}$ showed that physicians from areas at higher risk of local accidental infection for CD were more likely to consider $C D$ as diagnosis if the patients had Hispanic ethnicity. All authors evaluated healthcare workers' capability of identifying symptoms of the disease, except for Lambert et al., ${ }^{31}$ and the worst result was in Verani et al., ${ }^{38}$ with only $32 \%$ correct answers among participants. Etiology was described by the same studies, and Verani et al. ${ }^{38}$ also showed the worst frequency of correct answers about the etiological agent (58\%).

Studies in countries with ongoing transmission. Five articles about studies in countries with ongoing vector transmission were found, of which three were from Mexico ${ }^{27,32,37}$ and two from Brazil. ${ }^{28,35}$ Qualitative analysis defined four studies as high quality ${ }^{27,32,35,37}$ and one ${ }^{28}$ as moderate quality. All studies were conducted through structured surveys, administered by the researchers, except for Rodrigues et al. ${ }^{35}$ who also used focus groups and recording methods to elucidate conflicting results. Lugo-Caballero et al. ${ }^{32}$ and Berger et al. ${ }^{27}$ were the only studies to validate the research instrument and perform a pilot study. For recruited sample, Lugo-Caballero et al. ${ }^{32}$ and Berger et al. ${ }^{27}$ defined only physicians; Trivedi and Shangavi ${ }^{37}$ defined only nurses; Colosio et al. ${ }^{28}$ defined physicians, nurses, nurse assistants, and health workers; and Rodrigues et al. ${ }^{35}$ defined only community health agents (Table 3). The study by Berger et al. ${ }^{27}$ was the only study to describe social-epidemiologic characteristics of the sample.

All studies in countries with ongoing vector transmission analyzed clinical features, with an analysis in three of them at both acute and chronic phases of CD, ${ }^{27,28,35}$ in one of them only at the chronic phase, ${ }^{37}$ and in another one only at the acute phase of the disease. ${ }^{32}$ All selected studies questioned forms of transmission, except for Rodrigues et al. ${ }^{35}$ Trivedi and Shang$\mathrm{avi}^{37}$ only mentioned the recognition of the insect vector, which was correctly identified among $27 \%$ of participants. Rodrigues et al. ${ }^{35}$ investigated the ability to forward the suspected insects to a right destination, which were appointed as correct to $81.2 \%$ of the participants. The other studies of these countries evaluated the capability of identifying forms of transmission, which were incorrect in $52.6 \%{ }^{27}$ and $68 \%{ }^{32}$ of participants. In the study by Colosio et al., ${ }^{28}$ only $21 \%$ of participants recognized vertical transmission. Treatment was evaluated in all studies from countries with ongoing vector transmission, ${ }^{27,28,32}$ except for Rodrigues et al., ${ }^{35}$ and its results were incorrectly pointed by $31 \%,{ }^{28} 41 \%,{ }^{27}$ and $52 \%{ }^{32}$ of the responders, respectively. Diagnosis was correctly analyzed in $66 \%, 40 \%$, and more than $50 \%$ of participants in the study by Colosio et al., ${ }^{28}$ LugoCaballero et al., ${ }^{32}$ and Rodrigues et al., ${ }^{35}$ respectively. Most participants in the study by Rodrigues et al. ${ }^{35}$ considered having satisfactory knowledge about CD, and $60.7 \%$ affirmed the healthcare team had knowledge over symptomatology.

Studies in countries without vector transmission. Three studies conducted in countries without vector transmission were selected, all from Spain. ${ }^{30,33,34}$ Qualitative analysis classified all articles as high quality. The evaluation method used by MuñozVilches et al. ${ }^{33}$ applied a structured interview-administered survey. The sample composed of physicians and nurses, and described demographic aspects involving age, gender, and years of professional experience. The variables were symptomatology, transmission, diagnosis, treatment, and epidemiology, with correct answers in $54.3 \%, 71.6 \%, 70.6 \%, 41.4 \%$, and $56.9 \%$ of participants, respectively. Muñoz-Vilches et al. ${ }^{33}$ were the only authors to investigate the knowledge of oral transmission in their survey. In

TABLE 1

Characteristics of all studies selected for systematic review by countries

\begin{tabular}{|c|c|c|c|c|c|c|}
\hline $\begin{array}{l}\text { Sample } \\
\text { country }\end{array}$ & First author (year) & Type of study & $\begin{array}{c}\text { No. of } \\
\text { participants }\end{array}$ & Type of professional & $\begin{array}{l}\text { Study quality (critical } \\
\text { appraisal skills program) }\end{array}$ & Question model \\
\hline USA & Amstuz-Szalay ${ }^{26}$ & Cross-sectional & 105 & GP and SP & High $(7 / 10)$ & Multiple choice \\
\hline USA & Edwards et al. ${ }^{29}$ & Cross-sectional & 204 & SP & Moderate (4/10) & Multiple choice \\
\hline USA & Lambert et al. $^{31}$ & Cross-sectional & 22 & GP & Moderate $(5 / 10)$ & Open question \\
\hline USA & Stimpert and Montgomery ${ }^{36}$ & Cross-sectional & 1,142 & GP and SP & Moderate $(5 / 10)$ & Multiple choice \\
\hline USA & Verani et al. $^{38}$ & Cross-sectional & 421 & $\mathrm{SP}$ & High $(7 / 10)$ & Multiple choice \\
\hline Mexico & Lugo-Caballero et al. ${ }^{32}$ & Cross-sectional & 90 & GP & High (8/10) & Multiple choice \\
\hline Mexico & Berger et al. ${ }^{27}$ & Cross-sectional & 78 & GP and SP & High $(9 / 10)$ & Multiple choice \\
\hline Mexico & Trivedi and Sanghavi ${ }^{37}$ & Cross-sectional & 45 & NUR & High $(7 / 10)$ & Multiple choice \\
\hline Brazil & Colosio et al. $^{28}$ & Cross-sectional & 487 & $\mathrm{GP}, \mathrm{SP}, \mathrm{NUR}, \mathrm{NA}$, and $\mathrm{CHW}$ & Moderate $(5 / 10)$ & Multiple choice \\
\hline Brazil & Rodrigues et al. $^{35}$ & Cross-sectional & 65 & $\mathrm{CHW}$ & High $(8 / 10)$ & $\begin{array}{l}\text { Multiple choice, field } \\
\text { notes, and records }\end{array}$ \\
\hline Spain & Muñoz-Vilches et al. ${ }^{33}$ & Cross-sectional & 116 & SP and NUR & High (9/10) & Multiple choice \\
\hline Spain & Iglesias-Rus et al. $^{30}$ & Cross-sectional & 81 & GP and NUR & High (8/10) & Field notes and records \\
\hline Spain & Ramos Rincon et al. ${ }^{34}$ & Cross-sectional & 349 & GP and MS & High (9/10) & Multiple choice \\
\hline
\end{tabular}

$\mathrm{CHW}=$ community health worker; GP = general physician; $\mathrm{MS}=$ medical students; $\mathrm{NA}=$ nursing assistant; NUR = nurse; $\mathrm{SP}=\mathrm{specialist}$ physician . 
TABLE 2

Aspects of the instruments used in the studies

\begin{tabular}{|c|c|c|}
\hline Content aspects & Main types of questions by topic & Studies \\
\hline $\begin{array}{l}\text { Practical experience with } \\
\text { the disease }\end{array}$ & $\begin{array}{l}\text { Service experience } \\
\text { How often and do you consider the diagnosis? } \\
\text { How often do you investigate CD? } \\
\text { How to orientate a patient when encountering an } \\
\text { insect vector? }\end{array}$ & $\begin{array}{l}\text { Amstutz-Szalay }{ }^{26} \text {; Colosio et al. }{ }^{28} \text {; Edwards et al. }{ }^{29} \text {; } \\
\text { Lambert et al. }{ }^{31} \text {; Stimpert and Montgomery }{ }^{36} ; \\
\text { Verani et al.., }{ }^{38} \text { Rodrigues et al.., }{ }^{35} \text { Iglesias-Rus } \\
\text { et al. }{ }^{30}\end{array}$ \\
\hline $\begin{array}{l}\text { Objective knowledge on } \\
\text { clinical aspects }\end{array}$ & $\begin{array}{l}\text { Do you know the disease? } \\
\text { How is the diagnosis? What are the suggestive } \\
\text { findings? } \\
\text { What are the symptoms? } \\
\text { What is the treatment and effects? } \\
\text { What is the severity, evolution/prognosis? }\end{array}$ & $\begin{array}{l}\text { Amstutz-Szalay }{ }^{26} \text {; Colosio et al. }{ }^{28} \text {; Edwards et al. }{ }^{29} \text {; } \\
\text { Lambert et al. }{ }^{31} \text {; Stimpert and Montgomery } \\
\text { Verani et al. }{ }^{38} ; \text { Lugo-Caballero et al. }{ }^{32} \text {; Muñoz- } \\
\text { Vilches et al. }{ }^{33} ; \text { Trivedi and Sanghavi, }{ }^{37} \text { Ramos- } \\
\text { Rincon et al.., }{ }^{34} \text { Rodrigues et al. }{ }^{35}\end{array}$ \\
\hline Epidemiology & $\begin{array}{l}\text { Prevalence/incidence? } \\
\text { How common is it in the region? What is the } \\
\text { geographical distribution? } \\
\text { Is CD endemic in this region? }\end{array}$ & $\begin{array}{l}\text { Amstutz-Szalay }{ }^{26} ; \text { Edwards et al. }{ }^{29} ; \text { Trivedi and } \\
\text { Sanghavi, }{ }^{37} \text { Ramos-Rincon et al. }{ }^{34}\end{array}$ \\
\hline Transmission & $\begin{array}{l}\text { What is the etiological agent? } \\
\text { How is the transmission? } \\
\text { Do you recognize the vector? }\end{array}$ & 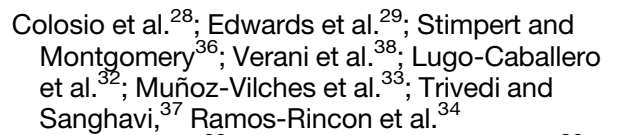 \\
\hline $\begin{array}{l}\text { Self-assessment of } \\
\text { knowledge }\end{array}$ & $\begin{array}{l}\text { Opinions on aspects of the disease } \\
\text { How do you evaluate yourself in capability to deal } \\
\text { with CD? }\end{array}$ & $\begin{array}{l}\text { Amstutz-Szalay }{ }^{26} \text {; Stimpert and Montgomery }{ }^{36} \text {; } \\
\text { Verani et al. }{ }^{38} \text {; Muñoz-Vilches et al., }{ }^{33} \text { Rodrigues } \\
\text { et al. }{ }^{35}\end{array}$ \\
\hline
\end{tabular}

comparison between workers' study groups, more correct answers were found among physicians than among nurses $(93.6 \%$ and $68.1 \%$, respectively).

Ramos-Rincon et al. ${ }^{34}$ performed a survey with health students and residents. The instrument was designed and validated as Chagas Level of Knowledge Scale for medical and other health professionals. The study demonstrated differences between the mean number of correct answers of the group with health students and residents (7.0) from the potential aid workers' group (1.8). Only $23 \%$ of the health students and residents knew the treatment for CD; $59 \%$ knew that it could be transmitted congenitally. The results were better for the participants who had received information about CD previously (7.2 versus 4.3 correct answers).

Iglesias-Rus et al. ${ }^{30}$ used a different approach by performing a qualitative research with focus groups and observation to evaluate the knowledge of family physicians and nurses. Physicians showed better knowledge than nurses, but they considered themselves as having insufficient knowledge. None of the participants mentioned the congenital transmission of CD. Previous contact with CD from research, experience with patients, and personal concern were appointed as factors that could justify for some participants to have broader knowledge about the disease.

Considering all analyzed studies, most were classified as high quality, and the articles from Mexico and Spain stand out, which were of high quality. ${ }^{27,30,32-34,37}$ All studies, ${ }^{26-38}$ independent of country of origin, presented both the need to improve perception of CD among healthcare workers and the lack of knowledge about aspects of CD (Table 4).

\section{DISCUSSION}

Healthcare workers' knowledge about CD is essential for adequate management and control of the infection through proper tracking and prevention. However, the topic is not being well investigated according to the small number of studies found in our review, even though a broad literature search was performed. Furthermore, the studies adopted different types of questionnaires, mostly influenced by epidemiological characteristics and local needs of each study, hindering the expected synthesis of these results or comparisons.

The United States, which was defined as a country with accidental vector transmission, held most studies, as CD can be considered a concern especially because of the elevated immigration rates of Latin individuals from endemic areas of neglected tropical diseases (NTDs), and also because of an increase on infected newborns. ${ }^{39}$ Thus, the higher rates of congenital infection for CD led to a greater need to amplify the awareness and knowledge for professionals who are not used to manage the disease. ${ }^{40}$ Edwards et al. ${ }^{29}$ and Verani et al. ${ }^{38}$ prioritized medical specialists that were in major contact with congenitally infected patients.

The immigratory phenomena also influenced the spread of the disease in Europe, mostly in Spain, where there is a large number of Bolivian immigrants. ${ }^{41}$ Concern about the immigration impacts on healthcare systems also reflected in research founding, with an increase on European investments in NTDs in the last decade, including CD. ${ }^{42}$ Thus, a higher attention was provided to CD congenital infection, leading to confirmation of cost-effectiveness in screening of pregnant Hispanic women. ${ }^{41}$ However, unlike American studies, European studies did not prioritize vertical transmission, considering all general aspects of the disease, including vector transmission, even in a country without documented cases. ${ }^{30,33,34}$

In South America, the reduction in vector transmission by Triatoma infestans among countries such as Brazil, Peru, and Uruguay leads to an evident epidemiological transition, especially increasing the importance of active surveillance for recognition of clinical signs and vectors by the general population. ${ }^{43}$ Cross-sectional studies with population inquiries were performed to evaluate the community awareness and knowledge in historically affected regions. ${ }^{44-51}$ 
TABLE 3

Characteristics of sample population of selected studies by setting

\begin{tabular}{|c|c|c|c|c|}
\hline Study site & First author (year) & Type of profession & Setting & Targeting questions \\
\hline \multicolumn{5}{|c|}{ Accidental vector transmission } \\
\hline \multirow[t]{5}{*}{ United States } & $\begin{array}{l}\text { Stimpert and } \\
\text { Montgomery }\end{array}$ & $\begin{array}{l}\text { OB/GYN, infectologists, primary } \\
\text { care givers, transplants } \\
\text { doctors, and cardiologists }\end{array}$ & Online & General aspects \\
\hline & Verani et al. ${ }^{38}$ & OB/GYN & Online & Focused on specialty \\
\hline & Edwards et al. ${ }^{29}$ & Pediatric infectologists & Online & Focused on specialty \\
\hline & Lambert et al. ${ }^{31}$ & Physicians in general & Online & General aspects \\
\hline & Amstutz-Szalay ${ }^{26}$ & $\begin{array}{l}\text { Cardiologists, emergencists, and } \\
\text { family physicians }\end{array}$ & Online & General aspects \\
\hline \multicolumn{5}{|c|}{ Vector transmission in progress } \\
\hline \multirow[t]{3}{*}{ Mexico } & Lugo-Caballero et al. ${ }^{32}$ & $\begin{array}{l}\text { Medical undergraduate on social } \\
\text { service }\end{array}$ & Primary care & General aspects \\
\hline & Trivedi and Sanghavi $^{37}$ & Blood bank screening nurses & Blood banks & General aspects \\
\hline & Berger et al. 27 & Physicians & On-line & General aspects \\
\hline \multirow[t]{2}{*}{ Brazil } & Colosio et al. ${ }^{28}$ & $\begin{array}{l}\text { Physicians, nurses, nursing } \\
\text { assistants, and } \mathrm{CHW}\end{array}$ & Primary care & General aspects \\
\hline & & \multicolumn{2}{|c|}{ No vector transmission } & General aspects \\
\hline \multirow[t]{4}{*}{ Spain } & Muñoz-Vilches et al. ${ }^{33}$ & Physicians and nurses & $\begin{array}{l}\text { Public hospitals: Areas of } \\
\text { Gynecology and pediatrics }\end{array}$ & General aspects \\
\hline & Ramos-Rincon et al. ${ }^{34}$ & $\begin{array}{l}\text { Physicians, medical students, and } \\
\text { health students }\end{array}$ & Health/student meetings & General aspects \\
\hline & Iglesias-Rus et al. ${ }^{30}$ & Familial physician and nurses & Primary care & General aspects \\
\hline & Ramos-Rincón et al. ${ }^{34}$ & $\begin{array}{l}\text { Physician, medical and health } \\
\text { students, and pharmacists }\end{array}$ & $\begin{array}{l}\text { Health/student conferences } \\
\text { and classes }\end{array}$ & General aspects \\
\hline
\end{tabular}

Residents of endemic areas showed a good perception and capacity of identifying the vector, but generally they were not able to recognize the importance of the disease and its consequences to their health, ${ }^{44-49}$ except in Brazilian studies. ${ }^{50}$ Thereby, proximity to routine local practice was determinant to increase awareness of the disease's existence, but it was not sufficient to engage people on prevention because individuals were not aware of the disease's implications, pointing to a knowledge deficit. ${ }^{44-49}$

Brazilian studies showed a satisfactory knowledge about prevention, risk factors, and the vector related to the disease among the community. Despite that, even in areas with good results, Villela et al. ${ }^{50}$ showed a decrease in knowledge among younger generations due to a longer time duration from the period when the disease was not yet controlled, reinforcing the need for continued education in risk areas.

Studies in ongoing vector transmission areas demonstrated better knowledge related to vectors, but not regarding other forms of transmission. ${ }^{27,28,32,35,37}$ Trivedi and Shangavi ${ }^{37}$ estimated that the unfamiliarity with CD by nurses in blood banks' triages could be responsible for infecting around 600,000 blood bags before the nationwide mandate of screening for CD. Muñoz-Vilches et al., ${ }^{33}$ Iglesias-Rus et al., ${ }^{30}$ Ramos-Rincon et al., ${ }^{34}$ and Colosio et al. ${ }^{28}$ demonstrated that medical workers tend to have more accurate answers regarding CD than nurses and other health workers. Because of the different types of questionnaires, the comparison between professionals was not possible in other studies.

Therefore, irrespective of forms of transmission and similarities with local routine, it is essential to include CD as a subject in develop continued education programs for health professionals, not only for improving their clinical practice and capability of recognizing CD but also for the ability of passing this knowledge to the community where they are allocated. ${ }^{17}$
Ramos-Rincon et al., ${ }^{34}$ Iglesias-Rus et al., ${ }^{30}$ and Berger et al. ${ }^{27}$ showed that previous training can improve knowledge degree. The early identification can also reduce the financial burden to healthcare systems due to CD. ${ }^{52}$

Regardless of the study area, there is a general lack of knowledge among health professionals about clinical and epidemiological aspects of CD. ${ }^{26-38}$ The worst results were related to self-perception of knowledge and consideration at diagnosis, with a need for interventions aiming the implementation of the staff confidence on diagnosis, especially among endemic regions. Otherwise, the review showed an increase tendency in research founding for CD higher than the disease burden of DALYS, ${ }^{53}$ whereas American studies suggest the reappearance of CD. ${ }^{54-57}$ Thereby, training healthcare workers in promoting active surveillance of the community is presented as an effective strategy for prevention of the reappearance of the disease.

A limitation of this study was the small number of articles found in the literature, especially from endemic areas, even with most of them being classified as high-quality studies. Even though Latin American countries such as Peru, Argentina and Bolivia $^{43}$ present remarkable burden of CD, they did not perform studies regarding healthcare professionals' knowledge, impairing comparisons between endemic and non-endemic areas. One study suggested that web surveys or surveys sent by e-mail allow professionals to gather information about CD before they start answering the questions, what may result in an overestimation of their knowledge. ${ }^{31}$ The use of online questionnaires can also be associated with selection bias, as some responders could have been affected to subject preference or unawareness in the process of decision to participate. Furthermore, the questionnaires did not follow a standard model. They were different according to the epidemiologic area of the study, which impaired generalization and comparisons. 
TABLE 4

Results and conclusions of studies

\begin{tabular}{|c|c|c|}
\hline First authors (year) & Main results & Conclusions \\
\hline Amstuz-Szalay ${ }^{26}$ & $\begin{array}{l}\text { 82.8\% with limited knowledge, } 1 \% \text { did not know the disease, } 17.2 \% \text { with } \\
\text { excellent or good knowledge, and } 88.5 \% \text { did not consider CD as a possible } \\
\text { diagnosis. }\end{array}$ & $\begin{array}{l}\text { Need to increase translation services in the } \\
\text { region and interventions aimed at } \\
\text { increasing the likelihood of recognition of } \\
\text { patients at risk for the disease. }\end{array}$ \\
\hline Edward et al. ${ }^{29}$ & $\begin{array}{l}99.5 \% \text { knew that CD is caused by a parasite and } 90.3 \% \text { knew that cure rates } \\
\text { for congenital CD exceed } 90 \% \text { when treatment is instituted in the first } \\
\text { weeks of life. } 50.2 \% \text { considered themselves with "limited" knowledge and } \\
17.9 \% \text { "very limited." } 80.9 \% \text { reported that at least } 1 \% \text { of their patients were } \\
\text { children of Latino immigrants, but } 75.6 \% \text { reported that they "never" or } \\
\text { "rarely" considered a diagnosis of congenital CD in newborns of Latin } \\
\text { American origin. }\end{array}$ & $\begin{array}{l}\text { Increased awareness among members of the } \\
\text { sampled society, as leaders in childcare, } \\
\text { could lead to a diagnostic evaluation of at- } \\
\text { risk babies and better long-term outcomes } \\
\text { of congenital CD. }\end{array}$ \\
\hline Lambert et al. ${ }^{31}$ & $\begin{array}{l}22 \text { physicians responded to the study, eight classified } C D \text { as potential } \\
\text { diagnosis, and } 14 \text { did not. Physicians who practice within the geographic } \\
\text { range of higher risk for } C D \text { are more likely to consider it in the differential } \\
\text { diagnosis of Hispanic patients than for Caucasian and African American } \\
\text { patients }(P<0.05) \text {. Qualitative analysis revealed that travel history is a } \\
\text { concern of some physicians. }\end{array}$ & $\begin{array}{l}\text { It is necessary to outline the areas with the } \\
\text { highest risk of transmission, followed by } \\
\text { the implementation of an action plan that } \\
\text { includes educating both the general } \\
\text { population and public health officials. }\end{array}$ \\
\hline $\begin{array}{l}\text { Stimpert and } \\
\text { Montgomery }^{36}\end{array}$ & $\begin{array}{l}29-60 \% \text { never considered the risk for CD in their patient population. The } \\
\text { general lack of consciousness was common in all groups, more } \\
\text { pronounced in obstetricians and gynecologists, and less pronounced in } \\
\text { infectious disease physicians. }\end{array}$ & $\begin{array}{l}\text { Substantial knowledge deficit on CD among } \\
\text { health professionals, which could have a } \\
\text { negative effect on patient health if CD is not } \\
\text { recognized and adequately treated. }\end{array}$ \\
\hline Verani et al. ${ }^{38}$ & $\begin{array}{l}77 \% \text { described their level of knowledge about CD as "very limited" or "never } \\
\text { heard of." Although } 66.9 \% \text { reported that at least } 1 \% \text { of the population } \\
\text { served is from Mexico, Central America, or South America, } 78 \% \text { reported } \\
\text { "never" considering a diagnosis of CD among their patients in those } \\
\text { regions. For five questions with defined correct answers, } 61 \% \text { provided at } \\
\text { least one correct answer. Only } 1 \% \text { got the five questions right. }\end{array}$ & $\begin{array}{l}\text { Increased awareness of CD can help detect } \\
\text { treatable birth cases in the United States. }\end{array}$ \\
\hline $\begin{array}{l}\text { Lugo-Caballero } \\
\text { et al. } .^{32}\end{array}$ & $\begin{array}{l}90 \% \text { of participants had already diagnosed before a vector-borne disease; } \\
68 \% \text { consider it to be transmitted only by the vector. For } 78.6 \% \text { of } \\
\text { physicians, a patient with asthenia, adynamia, and edematous eyelid injury } \\
\text { may suggest a case of CD. } 57 \% \text { would consider using a chest X-ray to } \\
\text { support the diagnosis of cardiomegaly. }\end{array}$ & $\begin{array}{l}\text { Evidence justifies the establishment of a } \\
\text { continuing education program on vector- } \\
\text { borne diseases in areas of high endemicity, } \\
\text { such as Mexico. }\end{array}$ \\
\hline Berger et al. ${ }^{27}$ & $\begin{array}{l}\text { Knowledge of the basic clinical aspects of CD and screening practices } \\
\text { differed if the interviewees had a history of previous training. Statistical } \\
\text { difference in knowledge was observed based on the duration of medical } \\
\text { practice or level of confidence in relation to knowledge of CD, with higher } \\
\text { mean scores of knowledge and higher probability of screening. }\end{array}$ & $\begin{array}{l}\text { Despite presenting better results than } \\
\text { previous studies and from other countries, } \\
\text { they concluded that further studies were } \\
\text { still needed to be carried out and compared } \\
\text { with educational measures. }\end{array}$ \\
\hline $\begin{array}{l}\text { Trivedi and } \\
\text { Sanghavi }{ }^{37}\end{array}$ & $\begin{array}{l}80 \% \text { of nurses responded to at least one question incorrectly or incompletely, } \\
\text { and } 13 \% \text { of the nurses answered at least two questions incorrectly or } \\
\text { incompletely. }\end{array}$ & $\begin{array}{l}\text { Hypothesis that if } 80 \% \text { of nurses are unaware } \\
\text { of the risk factors for CD, up to } 600,000 \\
\text { units of blood in Mexico are not effectively } \\
\text { screened each year. }\end{array}$ \\
\hline Colosio et al. ${ }^{28}$ & $\begin{array}{l}51 \% \text { did not correctly relate the symptomatology of the acute phase, } 65 \% \\
\text { correctly hit the chronic form, } 96 \% \text { said they requested the Machado- } \\
\text { Guerreiro reaction to confirm the diagnosis of Trypanosoma cruzi infection, } \\
98 \% \text { of the physicians demonstrated clarification regarding the vector } \\
\text { form, and } 79 \% \text { regarding transfusion. The congenital form was reported by } \\
21 \% \text { of these professionals. }\end{array}$ & $\begin{array}{l}\text { There is a lack of knowledge of professionals } \\
\text { from all classes working in primary care } \\
\text { involved in the study, with regard to } \\
\text { relevant aspects of the disease. }\end{array}$ \\
\hline $\begin{array}{l}\text { Rodrigues } \\
\text { et al. }{ }^{35}\end{array}$ & $\begin{array}{l}75 \% \text { consider professionals had satisfactory knowledge about CD, and } \\
60.7 \% \text { affirmed the health team knew the symptoms and above } 50 \% \text { knew } \\
\text { the diagnostic examinations. } 76 \% \text { of the community health agents } \\
\text { affirmed the health team knew how to forward suspected insect vector. }\end{array}$ & $\begin{array}{l}\text { The study highlights the existence of gaps } \\
\text { and unawareness of the health } \\
\text { professionals about the primary care } \\
\text { system associated with CD in the } \\
\text { investigated cities. }\end{array}$ \\
\hline $\begin{array}{l}\text { Muñoz-Vilches } \\
\text { et al. }\end{array}$ & $\begin{array}{l}78.4 \% \text { and } 71.6 \% \text { correctly adjusted the mechanisms of transmission and } \\
\text { diagnosis, respectively. } 54.3 \% \text { of the professionals knew the clinical } \\
\text { manifestations. } 41.4 \% \text { agreed to treat the disease, and } 50 \% \text { of the } \\
\text { professionals knew that the treatment is more effective and better tolerated } \\
\text { in children than adults. }\end{array}$ & $\begin{array}{l}\text { "The lack of training in CD to care for pregnant } \\
\text { women at risk of having the disease and } \\
\text { their children makes it necessary to start } \\
\text { training activities to expand this } \\
\text { knowledge, as well as to raise awareness } \\
\text { among health authorities." }\end{array}$ \\
\hline $\begin{array}{l}\text { Iglesias-Rus } \\
\text { et al. }\end{array}$ & $\begin{array}{l}\text { Family physicians considered having insufficient knowledge of CD but had } \\
\text { broader knowledge than nurses. Previous contact with the disease was } \\
\text { associated with broader knowledge by the participants. Congenital } \\
\text { transmission was not mentioned during the focus group discussions. } \\
\text { Some of the participants mistake CD with Zika virus. Even in the absence of } \\
\text { knowledge, some health workers demonstrated will to learn. }\end{array}$ & $\begin{array}{l}\text { "The results show the lack of knowledge } \\
\text { about CD, the epidemiology in a non- } \\
\text { endemic country, and the heterogeneity of } \\
\text { practices of primary care professionals in } \\
\text { the management of this health problem" }\end{array}$ \\
\hline $\begin{array}{l}\text { Ramos-Rincon } \\
\text { et al. }^{34}\end{array}$ & $\begin{array}{l}\text { The mean score of the healthcare students and residents was } 7.0 ; 67.1 \% \\
\text { knew about transmission through blood transfusions, } 59 \% \text { knew about } \\
\text { congenital transmission, and only } 23 \% \text { knew the drug used on the } \\
\text { treatment of CD. Those with previous information about CD had better } \\
\text { scores on the scale. }\end{array}$ & $\begin{array}{l}\text { The application of the scale showed a higher } \\
\text { rate of correct answers among those who } \\
\text { had received previous information on CD. } \\
\text { The study reaffirms the need to continue } \\
\text { training on neglected tropical diseases in } \\
\text { healthcare workers and students. }\end{array}$ \\
\hline
\end{tabular}




\section{CONCLUSION}

Chagas disease is an illness of global relevance, in which health surveillance plays an important role. This review shows that few studies were performed regarding healthcare workers' knowledge about CD. Most studies identified a lack of basic knowledge among the participants. There is a need for more studies about this subject, especially among areas in danger for the reappearance of the disease, so that resources and funding can be directed according to major deficits in each region.

Received September 14, 2020. Accepted for publication December 17, 2020.

Published online March 8, 2021.

Financial support: This study was funded by CNPq process 400904/ 2013-6-PROEP.

Title: Multidisciplinary Interinstitutional Project for the Study of Chagas Disease in the State of Bahia FAPESB Grant Term PET0023_2013.

Title: Environmental Changes and Risk of Re-emergence of Chagas Disease in Salvador, Ba. - Neglected Diseases.

Authors' addresses: Alice Monteiro Soares Cajaiba-Soares and Rita de Cássia Pereira Fernandes, Universidade Federal da Bahia, Faculdade de Medicina da Bahia, Salvador, Brazil, E-mails: alicecajaiba@ gmail.com and ritafernandes@ufba.br. Martha Silvia MartinezSilveira, Instituto Gonçalo Muniz, Fundação Oswaldo Cruz, Salvador, Brazil, E-mail: martha.silveira@fiocruz.br. Diego Lopes Paim Miranda, Laboratório de Patologia e Biologia Molecular, Fiocruz Bahia, Salvador, Brazil, E-mail: diegolpmiranda@hotmail.com. Mitermayer Galvão Reis, Instituto Gonçalo Muniz, Fundação Oswaldo Cruz, Salvador, Brazil, Universidade Federal da Bahia, Faculdade de Medicina da Bahia, Salvador, Brazil, and Department of Epidemiology of Microbial Diseases, Yale University School of Public Health, New Haven, CT, E-mail: mitermayer.reis@fiocruz.br.

\section{REFERENCES}

1. Kropf SP, Sá MR, 2009. The discovery of Trypanosoma cruzi and Chagas disease (1908-1909): tropical medicine in Brazil. Hist Cienc Saude Manguinhos 16 (Suppl 1): 13-34.

2. Chagas C, 1909. Nova tripanozomiaze humana: estudos sobre a morfolojia e o ciclo evolutivo do Schizotrypanum cruzin. gen., $\mathrm{n}$. sp., ajente etiolojico de nova entidade morbida do homem. Mem Inst Oswaldo Cruz 1: 159-218.

3. Bello Corassa R, Aceijas C, Alves PAB, Garelick H, 2017. Evolution of Chagas' disease in Brazil. Epidemiological perspective and challenges for the future: a critical review. Perspect Public Health 137: 289-295.

4. Ministério da Saúde (Brasil), Agencia Nacional de Vigilância Sanitária, 2004. Manual técnico para investigação da transmissão de doenças pelo sangue. Brasilia, Brazil: Ministerio da Saude. Available at: http:// bvsms.saude.gov.br/bvs/publicacoes/manual_tecnico_ transmissao_doencas_sangue.pdf Accessed July 31, 2020.

5. Coura JR, Dias JCP, 2009. Epidemiology, control and surveillance of Chagas disease: 100 years after its discovery. Mem Inst Oswaldo Cruz 104: 31-40.

6. Dias JCP, 2007. Globalização, iniqüidade e doença de Chagas. Cad Saude Publica 23: S13-S22.

7. Dias JP et al., 2008. Acute Chagas disease outbreak associated with oral transmission. Rev Soc Bras Med Trop 41: 296-300.

8. Ianni BM, Mady C, 2005. Como era gostoso o meu caldo de cana. Arq Bras Cardiol 85: 379-381.

9. de Noya BA et al., 2015. Update on oral Chagas disease outbreaks in Venezuela: epidemiological, clinical and diagnostic approaches. Mem Inst Oswaldo Cruz 110: 377-386.

10. World Health Organization, 2018. Chagas Disease (American Trypanosomiasis): Epidemiology. Geneva, Switzerland: WHO. Available at: https://www.who.int/chagas/epidemiology/en/. Accessed July 30, 2020.
11. GBD2015 DALYs, Hale Collaborators, 2016. Global, regional, and national disability-adjusted life-years (DALYs) for 315 diseases and injuries and healthy life expectancy (HALE), 1990-2015: a systematic analysis for the Global Burden of Disease Study 2015. Lancet 388: 1603-1658.

12. Pan American Health Organization, World Health Organization, 2017. Neglected Infectious Diseases. Chagas Diseases: Key Facts. Available at: https://www.paho.org/hq/dmdocuments/ 2017/2017-cha-chagas-factsheet-work.pdf. Accessed July $31,2020$.

13. Martins-Melo FR, Ramos AN, Alencar CH, Heukelbach J, 2014. Prevalence of Chagas disease in Brazil: a systematic review and meta-analysis. Acta Trop 130: 167-174.

14. de Oliveira CM, Cruz MM, 2015. Sistema de Vigilância em Saúde no Brasil: avanços e desafios. Saúde Debate 39: 255-267.

15. Gascon J, Bern C, Pinazo MJ, 2010. Chagas disease in Spain, the United States and other non-endemic countries. Acta Trop 115: 22-27.

16. Rosenthal EL, Brownstein JN, Rush CH, Hirsch GR, Willaert AM, Scott JR, Holderby LR, Fox DJ, 2010. Community health workers: part of the solution. Health Aff (Millwood) 29: 1338-1342.

17. Falavigna-Guilherme AL, Costa AL, Batista O, Pavanelli GC, de Araújo SM, 2002. Atividades educativas para o controle de triatomíneos em área de vigilância epidemiológica do Estado do Paraná, Brasil. Cad Saude Publica 18: 1543-1550.

18. Moher D, Liberati A, Tetzlaff J, Altman DG, 2009. Preferred reporting items for systematic reviews and meta-analyses: the PRISMA statement. J Clin Epidemiol 62: 1006-1062.

19. Oxford Centre for Triple Value Healthcare, 2018. Critical Appraisal Skills Programme Qualitative Checklist. Available at: https:// casp-uk.net/wp-content/uploads/2018/01/CASP-QualitativeChecklist-2018.pdf. Accessed June 21, 2020.

20. Madigan S, Ly A, Rash CL, Van Ouytsel J, Temple JR, 2018. Prevalence of multiple forms of sexting behavior among youth. JAMA Pediatr 172: 327-335.

21. Colosio RC, Falavigna-Guilherme AL, Gomes ML, Marques DSO, Lala ERP, Araújo SM, 2008. Conhecimentos e atitudes sobre a doença de Chagas entre profissionais de saúde - Paraná, Brasil. Cien Cuidado Saúde 6: 355-363.

22. Ramos-Rincon JM, Mira-Solves JJ, Ramos-Sesma V, TorrúsTendero D, Llenas-García J, Navarro M, 2020. Healthcare professionals and students' awareness of Chagas disease: design and validation of Chagas level of knowledge scale (ChaLKS). Am J Trop Med Hyg 103: 437-444.

23. Romo ML, 2014. Need for pharmacist awareness of Chagas disease. Am J Health Syst Pharm 71: 1069-1070.

24. Dell'Arciprete A, Braunstein J, Touris C, Dinardi G, Llovet I, SosaEstani S, 2014. Cultural barriers to effective communication between indigenous communities and health care providers in northern Argentina: an anthropological contribution to Chagas disease prevention and control. Int J Equity Health 13: 6.

25. Santos CS, 2019. As doenças negligenciadas e suas representações sociais: um estudo com profissionais de saúde. Faculdade de Enfermagem. Rio de Janeiro, Brazil: UFRJ, 245.

26. Amstutz-Szalay S, 2017. Physician knowledge of chagas disease in hispanic immigrants living in appalachian Ohio. J Racial Ethn Health Disparities 4: 523-528.

27. Berger BA, Bartlett $A H$, Jiménez-Hernández R, Vázquez $E T$, Galindo-Sevilla N, 2018. Physician knowledge, attitudes, and practices related to chagas disease in Tabasco, Mexico. Am J Trop Med Hyg 98: 1743-1747.

28. Colosio RC, Falavigna-Guilherme AL, Falavigna DLM, Gomes ML, de Oliveira Marques DS, Braga CF, Lala ERP, de Araujo SM, 2010. Professional conduct and knowledge gaps concerning Chagas disease in interrupted vector-borne transmission area. Arq Cien Saude UNIPAR 14: 3-9.

29. Edwards MS, Abanyie FA, Montgomery SP, 2017. Survey of pediatric infectious diseases society members about congenital Chagas disease. Pediatr Infect Dis J 37: e24-e27.

30. Iglesias-Rus L, Romay-Barja M, Boquete T, Benito A, BlascoHernández T, 2019. The role of the first level of health care in the approach to Chagas disease in a non-endemic country. PLOS Negl Trop Dis 13: e0007937. 
31. Lambert RC, Kolivras KN, Resler LM, Brewster CC, Paulson SL, 2008. The potential for emergence of chagas disease in the United States. Geospat Health 2: 227-239.

32. Lugo-Caballero Cl, Dzul-Rosado K, Dzul-Tut I, Balam-May Á, Zavala-Castro J, 2017. Knowledge of vector-borne diseases (dengue, rickettsiosis and Chagas disease) in physicians. Gac Med Mex 153: 321-328.

33. Muñoz-Vilches MJ, Salas-Coronas J, Gutiérrez-Izquierdo MI, Metz D, Salvador-Sánchez J, Giménez-Sánchez F, 2013. Conocimiento de la enfermedad de chagas por parte de los profesionales sanitarios de tres hospitales en la provincia de Almería. Rev Esp Salud Publica 87: 267-275.

34. Ramos-Rincón JM, Mira-Solves JJ, Ramos-Sesma V, TorrúsTendero D, Llenas-García J, Navarro M, 2020. Healthcare professionals and students' awareness of chagas disease: design and validation of chagas level of knowledge scale (ChaLKS). Am J Trop Med Hyg 103: 437-444.

35. Rodrigues FCS, de Souza ICA, Araújo AP, Souza JMB, Diotaiuti LG, Ferreira RA, 2020. Agentes comunitários de saúde: percepção sobre os serviços de saúde relacionados à doença de Chagas. Cad Saúde Colet 28: 130-139.

36. Stimpert KK, Montgomery SP, 2010. Physician awareness of Chagas disease, USA. Emerg Infect Dis 16: 871-872.

37. Trivedi M, Sanghavi D, 2010. Knowledge deficits regarding Chagas disease may place Mexico's blood supply at risk. Transfus Apher Sci 43: 193-196.

38. Verani JR, Montgomery SP, Schulkin J, Anderson B, Jones JL, 2010. Survey of obstetrician-gynecologists in the United States about Chagas disease. Am J Trop Med Hyg 83: 891-895.

39. Yadon ZE, Schmunis GA, 2009. Congenital chagas disease: estimating the potential risk in the United States. Am J Trop Med Hyg 81: 927-933.

40. Schmunis GA, 2007. Epidemiology of Chagas disease in non endemic countries: the role of international migration. Mem Inst Oswaldo Cruz 102: 75-86.

41. Sicuri E, Muñoz J, Pinazo MJ, Posada E, Sanchez J, Alonso PL, Gascon J, 2011. Economic evaluation of Chagas disease screening of pregnant Latin American women and of their infants in a non endemic area. Acta Trop 118: 110-117.

42. Olesen OF, Ackermann M, 2017. Increasing European support for neglected infectious disease research. Comput Struct Biotechnol J 15: 180-184.

43. Moncayo Á, Silveira AC, 2009. Current epidemiological trends for Chagas disease in Latin America and future challenges in epidemiology, surveillance and health policy. Mem Inst Oswaldo Cruz 104: 17-30.

44. Cabrera R, Mayo C, Suárez N, Infante C, Náquira C, GarcíaZapata MTA, 2003. Conocimientos, actitudes y prácticas sobre la enfermedad de Chagas en población escolar de una zona endémica del Perú. Cad Saude Publica 19: 147-154.

45. Donovan SD, Stevens M, Sanogo K, Masroor N, Bearman G, 2014. Knowledge and perceptions of Chagas disease in a rural Honduran community. Rural Remote Health 14: 2845.
46. Rosecrans K, Cruz-Martin G, King A, Dumonteil E, 2014. Opportunities for improved Chagas disease vector control based on knowledge, attitudes and practices of communities in the Yucatan peninsula, Mexico. PLoS Negl Trop Dis 8: e2763.

47. Salm A, Gertsch J, 2019. Cultural perception of triatomine bugs and Chagas disease in Bolivia: a cross-sectional field study. Parasit Vectors 12: 291.

48. Valdez-Tah A, Huicochea-Gómez L, Ortega-Canto J, NazarBeutelspacher A, Ramsey JM, 2015. Social representations and practices towards triatomines and chagas disease in Calakmul, México. PLoS One 10: e0132830.

49. Verdú J, Ruiz MT, Control del Chagas en comunidades guaraníes: conocimiento y hábitos higiénicos dentro del Proyecto de Mejoramiento de Viviendas en Bolivia. Gac Sanit 17: 166-168.

50. Villela MM, Pimenta DN, Lamounier PA, Dias JCP, 2009. Avaliação de conhecimentos e práticas que adultos e crianças têm acerca da doença de Chagas e seus vetores em região endêmica de Minas Gerais, Brasil. Cad Saude Publica 25: $1701-1710$.

51. Williams-Blangero S, VandeBerg JL, Teixeira AR, 1999. Attitudes towards Chagas' disease in an endemic Brazilian community. Cad Saude Publica 15: 7-13.

52. Bartsch SM, Avelis CM, Asti L, Hertenstein DL, Ndeffo-Mbah M, Galvani A, Lee BY, 2018. The economic value of identifying and treating Chagas disease patients earlier and the impact on Trypanosoma cruzi transmission. PLoS Negl Trop Dis 12: e0006809.

53. Shiffman J, 2006. Donor funding priorities for communicable disease control in the developing world. Health Policy Plan 21: 411-420.

54. Barbosa-Silva AN, de Cássia Moreira Souza R, Diotaiuti L, Aguiar LMA, da Câmara ACJ, Galvão LM, Chiari E, 2019. Synanthropic triatomines (Hemiptera: Reduviidae): infestation, colonization, and natural infection by trypanosomatids in the State of Rio Grande do Norte, Brazil. Rev Soc Bras Med Trop 52: e20190061.

55. Batista DG, Britto C, Monte GLS, Baccaro FB, 2019. Occurrence of triatomines (Hemiptera: Reduviidae) in domestic and natural environments in novo remanso, itacoatiara, Amazonas, Brazil. Rev Soc Bras Med Trop 52: e20190063.

56. Dye-Braumuller KC, Gorchakov R, Gunter SM, Nielsen DH, Roachell WD, Wheless A, Debboun M, Murray KO, Nolan MS, 2019. Identification of triatomines and their habitats in a highly developed urban environment. Vector Borne Zoonotic Dis 19: 265-273.

57. Ribeiro G, Gurgel-Gonçalves R, Reis RB, dos Santos CGS, Amorim A, Andrade SG, Reis MG, 2015. Frequent house invasion of Trypanosoma cruzi-infected triatomines in a suburban area of Brazil. PLoS Negl Trop Dis 9: e0003678. 